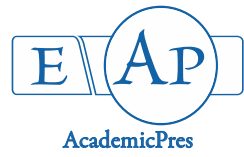

\title{
Isolation and Protein Characterization of Lindane Degrading Root Epiphytic Bacterium Artbrobacter sp. T16 from Typha latifolia
}

\author{
Tanvi SINGH*, Dileep K. SINGH \\ University of Delhi, Department of Zoology,Delhi, 110007, India; tanvi2112@gmail ("corresponding author); dileepksingh@gmail.com
}

\begin{abstract}
Lindane, extensively used as pesticide, causes severe environmental hazard and is a threat to the humanity. The present study aims to assess the capability and mechanism of root epiphytic bacteria of wetland plant Typha latifolia to degrade lindane. Isolation of lindane degrading root epiphytic bacteria was done by standard enrichment technique and lindane degradation analysis was done using Gas Liquid Chromatography. Bacterial strain Arthrobacter sp. T16 was isolated and identified, which showed maximum degradation of $71.2 \pm 1.3 \%$ of $50 \mathrm{mg} \mathrm{l}^{-1}$ lindane. Lindane biodegradation was accompanied with decrease in $\mathrm{pH}$, increase in chloride ions concentration of culture medium and a positive dechlorination assay. Biodegradation potential of Arthrobacter sp. T16 was also studied at different lindane concentrations. Maximum degradation was observed at $10 \mathrm{mg} \mathrm{l}^{-1}$ lindane followed by $50 \mathrm{mg} \mathrm{l}^{-1}$ and $100 \mathrm{mg} \mathrm{l}^{-1}$ lindane. Lindane biodegradation kinetics study inferred that the average rate of lindane degradation increased with increase in lindane concentration. Lindane induced proteins in Arthrobacter sp. T16 were studied by SDS-PAGE. Distinctive polypeptides came into view in the presence of lindane and were identified as putative $\mathrm{ABC}$ transporter periplasmic amino acid-binding protein, elongation factor $\mathrm{Tu}$ and trifunctional transcriptional regulator/proline dehydrogenase/pyrroline-5-carboxylate dehydrogenase, each expressed due to lindane stress. This study specifies the potential of phytoremediation in controlling the environmental contamination problem with the help of indigenous organisms present in roots of plants.
\end{abstract}

Keywords: accession number; bacterial suspension; half-life; mesocosm; pellet

\section{Introduction}

Lindane $(\gamma-\mathrm{HCH})$ is a chlorinated saturated hydrocarbon, extensively used as pesticide. Owing to its chemical properties, it persists in the environment, migrates over long distances with air, undergoes volatilization in tropical conditions, and gets deposited in colder regions, thus causing widespread contamination. Lindane residues also reach animals and humans by food chain and get bioamplified at each trophic level (Benimeli et al., 2008; Fuentes et al., 2010a; Jennings and Li, 2014; Polti et al., 2014). Its residues are found in soil, sediments, water, plants, animal tissues, and even in bodily fluids like breast milk, blood, and amniotic fluid (Vijgen et al., 2011; Alvarez et al., 2012a). It is classified as possible carcinogen as well as endocrine disruptor, accompanying confirmed mutagenicity, teratogenicity, and genotoxicity (Kaur et al., 2013). In 2006, more than 50 countries have taken up the convention on prohibiting or restricting the production and use of lindane. In 2009, lindane was incorporated among persistent organic pollutants (POPs) that cause severe environmental hazard (Draft Risk Management Evaluation for Lindane, 2007; Egorova et al., 2017). Though, its use has been disallowed or sternly limited in about 52 countries but it is still being used by some developing countries on economic grounds. The environmental contamination with lindane is a threat to the humanity. Therefore there is an urgent need for the advancement in technologies aiming to decontaminate lindane polluted sites.

Phytoremediation is a strategy to remediate organic contaminants by plant-microrganism interactions or numerous plant methods (Gerhardt et al., 2009; Alvarez et al., 2012b). Plants, in union with their rhizospheric, root epiphytic (bacteria present on the surface of roots) or endophytic microorganisms, have immense potential to degrade organic pollutants (Abhilash et al., 2011; Khan et al., 2013; Singh and Singh, 2017). Till date a number of studies have reported bioremediation of lindane by aquatic and soil microorganisms (Benimeli et al., 2007; Lal et al., 2010; Alvarez et al., 2012; Giri et al., 2014) but very little work has been done on bioremediation of lindane by root epiphytic or rhizospheric bacteria. Böltner et al. (2008) have studied HCH degrading Sphingomonas strains colonizing the roots of Zea mays. Sphingomonas sp., Devosia sp., 
560

Pseudomonas sp., and Sphingobium sp. possessing the ability to degrade $\mathrm{HCH}$ were isolated from the rhizosphere of Phragmites australis (Miguel et al., 2014).

Since organochlorine pesticides are toxic to a number of plant species, therefore the plants selected to be used in phytoremediation must flourish in pesticide polluted sites (Perez et al., 2008). In this study, we have chosen Typha latifolia for phytoremediation of lindane. Typha latifolia (broadleaf cattail) is a wetland species having high level of biomass, high growth rate, and well-developed root system and is well recognized in mitigating environmental pollution (Sukumaran, 2013; Strungaru et al., 2015). The present study attempts to assess the capability and mechanism of root epiphytic bacteria of Typha latifolia to degrade lindane. So far as known, this is the first report studying the isolation of lindane degrading bacteria from the root surface of Typha latifolia and characterizing the unique proteins expressed in the presence of lindane. The objectives of the study were to identify lindane degrading root surface bacteria of Typha latifolia, to study the degradation kinetics and lindane induced modification in protein profile of isolated bacteria.

\section{Materials and Methods}

\section{Chemicals and culture media}

Lindane (> $99 \%$ pure, purchased from Sigma Aldrich, USA) stock was prepared in ethyl acetate at the concentration of $5 \mathrm{mg} \mathrm{ml}^{-1}$, sterilized by filtering and added to the culture media. For bacterial isolation and degradation experiments, we used Mineral Salt Medium (MSM: Diammonium hydrogen orthophosphate, $0.5 \mathrm{~g} \mathrm{l}^{-1}$; Magnesium sulphate, $0.2 \mathrm{~g} \mathrm{1^{-1 }}$; Ferrous sulphate heptahydrate, $0.01 \mathrm{~g} \mathrm{l}^{-1}$; Dipotassium hydrogen orthophosphate, $0.1 \mathrm{gl}^{-1}$; Calcium nitrate tetrahydrate, 0.01 $\left.\mathrm{g}^{-1} \mathrm{pH} 7.0\right)$ and for the growth of isolated cultures, LB medium (Tryptone $10 \mathrm{~g} \mathrm{l}^{-1}$; Yeast extract, $5 \mathrm{~g} \mathrm{l}^{-1}$; Sodium chloride, $5 \mathrm{~g} \mathrm{l}^{-1}$; Glucose $1 \mathrm{~g} \mathrm{l}^{-1} \mathrm{pH}$ 7.0). All the chemicals were of analytical grade and purchased from standard manufacturers.

\section{Root sampling}

The root samples were collected from established wetland mesocosms maintained at IARI, Delhi $\left(28^{\circ} 38^{\prime}\right.$ $21.3^{\prime \prime} \mathrm{N}$ and $77^{\circ} 08^{\prime} 56.5^{\prime \prime} \mathrm{E}$ ). IARI campus is traversed by a network of sewage drains that receive domestic and industrial effluents generated by the campus as well as commercial, agricultural, industrial, and dwelling units around IARI. The experimental mesocosms are planted with Typha latifolia and flooded with wastewater. Roots sections of about $15 \mathrm{~cm}$ were carefully cut from the plants in a way as not to destroy the plants. Roots from three to five individual plants were combined to form sufficient sample for study. The samples were collected in sterile sampling bags. They were taken to lab in containers filled with ice where temperature inside did not exceed $7^{\circ} \mathrm{C}$. Samples were stored at $4^{\circ} \mathrm{C}$ in the lab and were analyzed the same day.

\section{Isolation of lindane degrading root epiphytic bacteria}

Isolation of root epiphytic bacteria was carried out by standard enrichment technique. Roots were gently washed twice in sterile distilled water and aseptically chopped into small pieces. Root surface bacteria were isolated by shaking small pieces of roots on a mechanical shaker in phosphate buffer saline (1X) at $150 \mathrm{rpm}$ for $1 \mathrm{~h} .5 \mathrm{ml}$ bacterial suspension was inoculated in $45 \mathrm{ml} \mathrm{MSM}$ containing $50 \mathrm{mg}$ $\mathrm{I}^{-1}$ lindane and incubated for seven days at $30^{\circ} \mathrm{C}$ on rotary shaker. Enrichment was carried out for a period of five weeks. Spread plate and streaking method were used to obtain pure isolates.

\section{Lindane degradation in liquid culture and identification of strain}

The bacterial isolates showing luxurious growth on MSM (with lindane) agar plates were subjected for degradation study. Lindane degradation study was conducted in $100 \mathrm{ml}$ MSM supplemented with $50 \mathrm{mg} \mathrm{l}^{-1}$ lindane. Bacterial pellets of $1 \mathrm{ml}$ culture grown in LB were used to inoculate experimental flasks. Controls flasks spiked with lindane were uninoculated. Degradation experiment was set in microbial shaker at $30^{\circ} \mathrm{C}$ with $150 \mathrm{rpm}$ for 15 days. Analysis of lindane degradation was done using Gas Liquid Chromatography (Agilent 7890A) equipped with $63 \mathrm{Ni}$ Electron capture Detector (ECD) and HP 05 column. The GC oven temperature was programmed for an initial temperature of $150^{\circ} \mathrm{C}$ then hold for $2 \mathrm{~min}$, ramped at a rate of $5^{\circ} \mathrm{C} \min ^{-1}$ till1 $180{ }^{\circ} \mathrm{C}$ and hold for $3 \mathrm{~min}$ and finally ramped at a rate of $10^{\circ} \mathrm{C} \mathrm{min}^{-1}$ to $210^{\circ} \mathrm{C}$ and hold at $210^{\circ} \mathrm{C}$ for $5 \mathrm{~min}$. The injector and interface temperatures were $220^{\circ} \mathrm{C}$ and $250^{\circ} \mathrm{C}$, respectively. Nitrogen was used as carrier gas. $1 \mu \mathrm{l}$ of sample was injected in split mode (pulse pressure $=12$ psi, split ratio 100:1 and purge flow $3 \mathrm{ml} \mathrm{min}^{-}$ $\left.{ }^{1}\right)$. Obtained peak area and their retention time $\left(\mathrm{R}_{\mathrm{t}}\right)$ were used to study lindane degradation. OD $\lambda_{2595 n}$ and $\mathrm{pH}$ change during degradation were also studied.

The bacterial strain showing maximum lindane degradation was sequenced from SciGenome labs, India after $16 \mathrm{~S}$ rRNA gene amplification. The $16 \mathrm{~S}$ rRNA gene sequence was deposited in GenBank under accession number MF109974 and subjected to BLAST, using National Center for Biotechnology Information (NCBI)/Basic Local Alignment Search Tool (BLAST) program (http://blast.ncbi.nlm.nih.gov/Blast.cgi). The biochemical characteristics of the isolated strains are presented in Table 1.

\section{Dechlorination assay}

Dechlorination assay of lindane was performed by the method described by Phillips et al. (2001). In a 96-well microtitre plate, three types of wells were made. First set contained assay buffer (Hepes buffer, Sodium sulphate and $\mathrm{Na}_{2}$ EDTA, $\mathrm{pH} 8$ ), second set had assay buffer and cell free extract of bacteria, third treatment had assay buffer, cell free extract of bacteria and substrate (lindane $10 \mathrm{mg} \mathrm{l}^{-1}, 50 \mathrm{mgl}^{-1}$ and $100 \mathrm{mg} \mathrm{l}^{-1}$ ). The microtitre plate was covered and incubated for $6-8 \mathrm{~h}$ at $30^{\circ} \mathrm{C}$. Change in color from red to yellow was observed.

Determination of chloride ion concentration was done according to the method described by Iwasaki et al. (1952). For this, bacterial strain was cultured in MSM supplemented with $50 \mathrm{mg} \mathrm{l}^{-1}$ lindane. $1 \mathrm{ml}$ sample was treated with mercuric thiocynate solution and ferric alum solution. The colour developed was measured at $\lambda_{460 \mathrm{~nm}}$ by spectrophotometer. The amount of $\mathrm{Cl}^{-}$release was calculated using a standard curve prepared using $\mathrm{KCl}$. 
Table 1. Biochemical characteristics of Arthrobacter sp. strain T16

\begin{tabular}{|c|c|}
\hline Gram staining & $\checkmark$ \\
\hline ONPG & - \\
\hline Lysine utilization & $\checkmark$ \\
\hline Ornithine utilization & $\checkmark$ \\
\hline Urease & $\checkmark$ \\
\hline Phenylalanine Deamination & - \\
\hline Nitrate reduction & $\checkmark$ \\
\hline $\mathrm{H}_{2} \mathrm{~S}$ production & - \\
\hline Citrate utilization & - \\
\hline Voges Proskauer's & - \\
\hline Methyl red & - \\
\hline Indole & - \\
\hline Malonate utilization & - \\
\hline Esculin hydrolysis & - \\
\hline Arabinose & - \\
\hline Xylose & - \\
\hline Adonitol & - \\
\hline Rhamnose & - \\
\hline Cellobiose & - \\
\hline Melibiose & - \\
\hline Saccharose & - \\
\hline Raffinose & - \\
\hline Trehalose & - \\
\hline Glucose & $\checkmark$ \\
\hline Lactose & - \\
\hline Oxidase & - \\
\hline Catalase & $\checkmark$ \\
\hline
\end{tabular}

Lindane degradation kinetics study

MSM was supplemented with different lindane concentration (10 $\mathrm{mg} \mathrm{l}^{-1}, 50 \mathrm{mg} \mathrm{l}^{-1}$ and $100 \mathrm{mg} \mathrm{l}^{-1}$ ) and inoculated with bacterial strain grown in LB medium. Extraction and degradation study of lindane were done as described previously. Average rate of lindane degradation at its different concentration was calculated using the following equation.

$\mathrm{r}_{\mathrm{av}}\left(\mathrm{mgl}^{-1} \mathrm{~d}^{-1}\right)=\mathrm{C}_{\mathrm{o}}-\mathrm{C}_{\mathrm{t}} /(\Delta \mathrm{t})$

where $\mathrm{Co}$ is concentration of lindane at time $0, \mathrm{Ct}$ is concentration at time $t, r_{a v}$ is the average rate of degradation and $\Delta \mathrm{t}$ is the duration of degradation study.

Lindane degradation kinetics was fitted using first-order kinetic equation which follows:

$\mathrm{C}_{\mathrm{t}}=\mathrm{C}_{\mathrm{o}}-\mathrm{e}^{\mathrm{kt}}$

where $\mathrm{C}_{\mathrm{o}}$ - initial concentration of lindane (at time 0 ), $\mathrm{C}_{\mathrm{t}}$-concentration of lindane at time $\mathrm{t}, \mathrm{K}$ is the degradation constant and $\mathrm{t}$ is reaction time.

The half-life $\left(t_{1 / 2}\right)$ of lindane biodegradation was calculated using the formula:

$\mathrm{t}_{1 / 2}=\ln 2 / \mathrm{k}$

\section{Protein profile of lindane degrading bacterial strain}

Protein profile of lindane degrading bacterial strain was studied. For this, bacteria were cultured under two different conditions: (i) with glucose as carbon source (without lindane) and (ii) lindane as sole source of carbon. The bacterial cells were harvested aseptically from culture by centrifugation $\left(8000 \mathrm{x} \mathrm{g}\right.$ for $10 \mathrm{~min}$ at $\left.4{ }^{\circ} \mathrm{C}\right)$. Obtained bacterial pellet was washed twice with sterile phosphate buffer saline ( $0.05 \mathrm{M}, \mathrm{pH} 6.8)$, subsequently pellet was dissolved in lysis buffer (Singh and Singh, 2014) and boiled in water bath for $10 \mathrm{~min}$. Lysate was cooled to room temperature and sonicated (nine pulses of $5 \mathrm{~s}$ and $5 \mathrm{~s}$ cooling) at amplitude of $9 \mathrm{~Hz}$. Concentration of protein in cell lysate was determined by Bradford method. Electrophoresis was done on discontinuous polyacrylamide gel (5\% stacking and 10\% separating gel) with $50 \mu \mathrm{g}$ protein/lane at $70 \mathrm{~V}$ (through stacking gel), further increasing voltage to $120 \mathrm{~V}$ (through resolving gel). Coomassie Brilliant Blue G-250 was used as staining dye for proteins. Gel was visualized on gel doc. Polypeptide bands were eluted using ammonium bicarbonate and 50\% acetonitrile solvent (Singh and Singh, 2014). MALDI-TOF MS/MS analysis was done at AIRF JNU, New Delhi

\section{Statistical analysis}

The mean of triplicates was analyzed using analysis of variance (ANOVA) with Graphpad Prism 7 software. P values less than 0.05 were considered significant.

\section{Results and Discussion}

\section{Lindane degradation and identification of bacteria}

In the present study we have isolated lindane degrading root epiphytic bacteria from wetland plant Typha latifolia by enrichment culture method. Eight morphologically distinct bacterial colonies capable of showing good growth on MSM agar plates (with lindane) were obtained using streak plate technique. Out of all bacterial strains, strain T16 showed maximum degradation potential of $71.2 \pm$ $1.3 \%$ of $50 \mathrm{mg} \mathrm{l}^{-1}$ lindane after 15 days in MSM broth at 30 ${ }^{\circ} \mathrm{C}$ (Fig. 1, 2a). In uninoculated flasks (control), lindane decreased by $5.09 \pm 0.16 \%$ (Fig. 2a) which can be attributed to abiotic factors. Analysis and NCBI BLAST result of the $16 \mathrm{~S}$ rRNA sequence of the isolated strain T16 showed similarity with genus Arthrobacter, therefore the strains was identified as Arthrobacter sp. strain T16. Earlier studies have also reported Arthrobacter sp. (Datta et al., 2000; De Paolis et al., 2013) to be capable of degrading hexachlorocyclohexane. Lindane degradation by Arthrobacter sp. strain T16 was accompanied by its growth in MSM (Fig. 2a), showing the utilization of lindane as sole carbon source. Sagar and Singh (2011) have also observed the growth of Fusarium sp. with lindane as sole source of carbon.

\section{Dechlorination assay}

Dehalogenation i.e. the removal of halogen atom from organic halogen compounds is the main reaction in microbial degradation of such compounds. Halogen atoms are usually responsible for the toxicity of these xenobiotic compounds and their elimination decreases defiance of these compounds towards biodegradation. In dehalogenation, halogen atoms are substituted by hydrogen or hydroxyl group (Camacho-Pérez et al., 2012).

In lindane degradation experiment of our study, $\mathrm{pH}$ of culture medium decreased significantly $(\mathrm{p}<0.05)$ during incubation period. However in uninoculated flasks 
562

(control), no significant change $(\mathrm{p}>0.05)$ in $\mathrm{pH}$ was observed (Fig. 2b). To find out that decrease in $\mathrm{pH}$ is due to dechlorination of lindane, dechlorination assay was done. A change in coloration of reaction mixture from red to yellow was observed after $6 \mathrm{hrs}$ of incubation in wells containing assay buffer, cell free extract of bacteria and substrate (lindane $10 \mathrm{mg} \mathrm{l}^{-1}, 50 \mathrm{mg} \mathrm{l}^{-1}$ and $100 \mathrm{mg} \mathrm{l}^{-1}$ ) (Fig. 3). No color change was observed in wells without lindane (substrate) (Fig. 3). Quantification of chloride ion concentration showed its gradual increase from 0 day to $15^{\text {th }}$ day of incubation (Fig. 2b) in experimental setup and no significant increase $(\mathrm{p}>0.05)$ was observed in control. Increase in chloride ion concentration in inoculated samples was statistically significant $(\mathrm{p}<0.05)$ as compared to 0 day. These results depict that Arthrobacter sp. T16, isolated from the root surface of Typha latifolia have potential to utilize lindane as source of carbon by degrading it. Similar results were obtained during lindane degradation study by Rhodotorula sp. VITJzN03 (Salam et al., 2013) and Streptomyces consortium in slurry system (Saez et al., 2015). Also, quite a few reports confirm dehalogenase activity in actinobacteria with lindane as substrate (Cuozzo et al., 2009; Fuentes et al., 2010a, b; Philip et al., 2014).

\section{Lindane degradation kinetics}

Lindane biodegradation by Arthrobacter sp. T16 was also observed in MSM supplemented with different concentrations of lindane. Maximum degradation was observed at $10 \mathrm{mg} \mathrm{l}^{-1}$ lindane followed by $50 \mathrm{mg} \mathrm{l}^{-1}$ and 100 $\mathrm{mg} \mathrm{l}^{-1}$ lindane (Fig. 4), indicating that increasing lindane concentration affected the degradation performance of bacteria. Paul et al., (2013) also observed higher lindane degradation at $10 \mathrm{mg} \mathrm{l}^{-1}$ as compared to $100 \mathrm{mg} \mathrm{l}^{-1}$ by Azotobacter chroococcum strains JL 15 and JL 104. This could be due to inhibitory effect of lindane on growth of bacteria. In our study, average rate of lindane degradation increased with increase in lindane concentration (Table 2) since the rate of reaction, at any time, depends on the concentrations of the reactants at that particular time. Similar results were obtained in studies of lindane biodegradation by Giri et al. (2014) and Pesce and Wunderlin (2004). Degradation kinetics of lindane is described well by first order reaction as it was dependent on the substrate concentration (Fig. 5). The kinetic rate constant $(k)$, half life $\left(t_{1 / 2}\right)$ and regression coefficient $\left(R^{2}\right)$ for all concentrations of lindane are presented in Table 2.

\section{Protein profile of Arthrobacter sp. T16}

To identify lindane induced proteins in Arthrobacter sp. T16, comparative analysis of protein profile was done by culturing the bacteria in the presence of glucose as carbon source (without lindane) as well as lindane as the only carbon source. Distinctive polypeptides came into view in lane resultant to MSM supplemented with lindane and these bands were not observed in the culture without lindane (Fig. 6). Bacterial exposure to lindane resulted in the regulative expression of certain proteins. Approximate molecular weight of distinctive polypeptide bands was estimated by Molecular Weight Analysis Tool of Image $\mathrm{Lab}^{\mathrm{TM}}$ software (version 3.0) using BlueRay prestained protein ladder $\left(10-180 \mathrm{kD}\right.$, GeneDireX $\left.{ }^{\mathrm{TM}}\right)$ as standard molecular weight marker. The molecular weight of polypeptides for Arthrobacter sp. T16 was estimated to be $36.6 \mathrm{kD}, 43.8 \mathrm{kD}$ and $137.4 \mathrm{kD}$, for band 1,2 and 3 respectively.
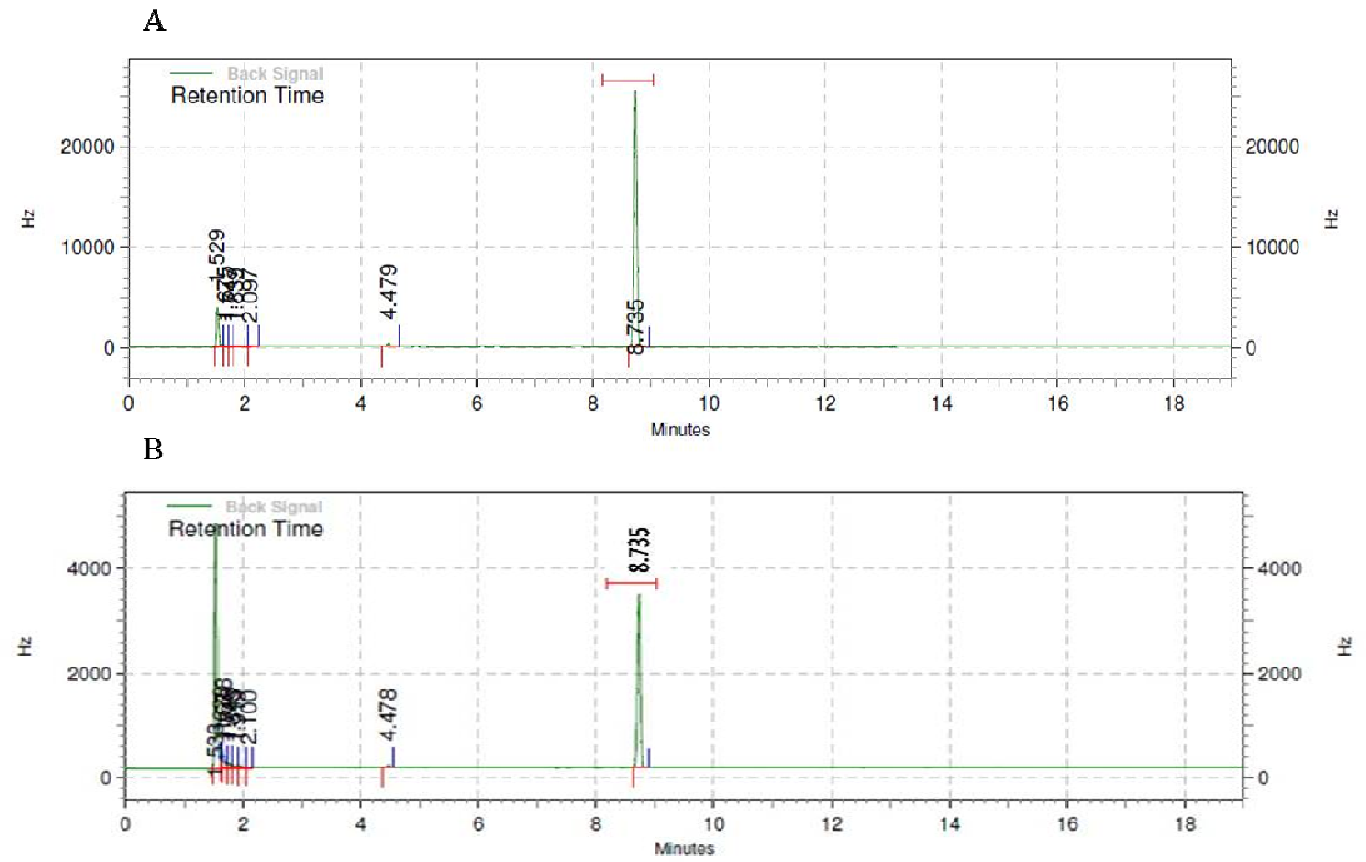

Fig. 1. GC analysis of lindane degradation at 0 day (a) and $15^{\text {th }}$ day (b) by Arthrobacter sp. T16. Lindane peak was observed at $\mathrm{R}_{\mathrm{t}}$ $8.375 \mathrm{~min}$. Decrease in peak area of lindane shows its degradation 
A

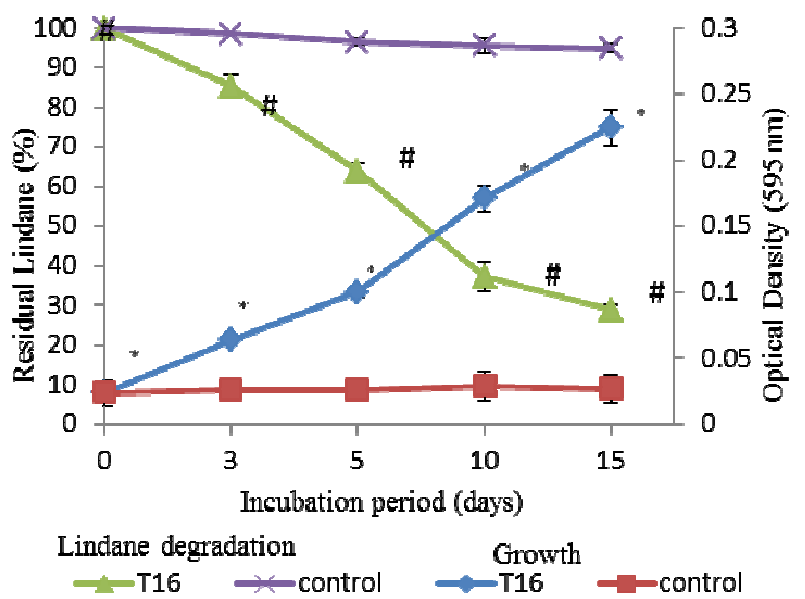

B

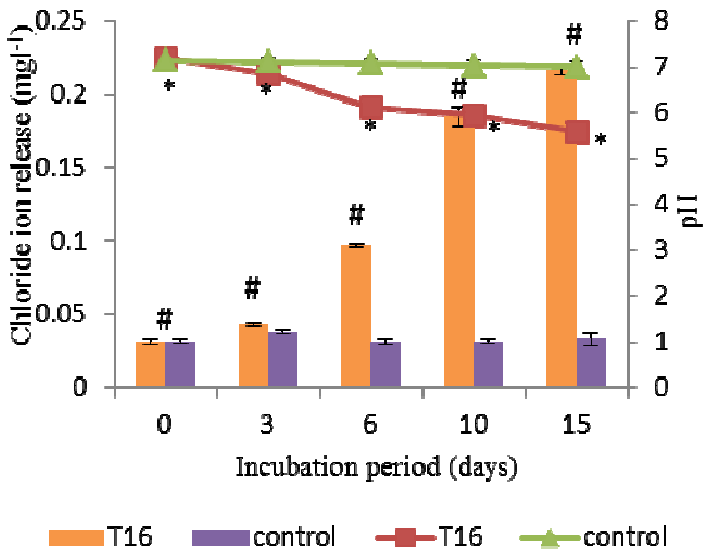

Fig. 2. (A) Degradation of lindane $\left(50 \mathrm{mg} \mathrm{l}^{-1}\right)$ and growth of Arthrobacter sp. T16 in liquid culture medium after 15 days of incubation. ${ }^{*}$ Significant difference $(\mathrm{p}<0.05)$ in growth of bacteria, ${ }^{*}$ Significant difference $(\mathrm{p}<0.05)$ in percentage degradation of lindane by bacterial strain during incubation period of 15 days (B) Chloride ion release and change in $\mathrm{pH}$ of broth medium during Lindane degradation by Arthrobacter sp. T16.* Significant decrease $(\mathrm{p}<0.05)$ in $\mathrm{pH}$, ${ }^{*}$ significant increase $(\mathrm{p}<0.05)$ in chloride ion concentration of the culture medium supplemented with lindane from 0 to $15^{\text {th }}$ day. Values are mean of three replicates. Error bars show $\pm \mathrm{SE}$

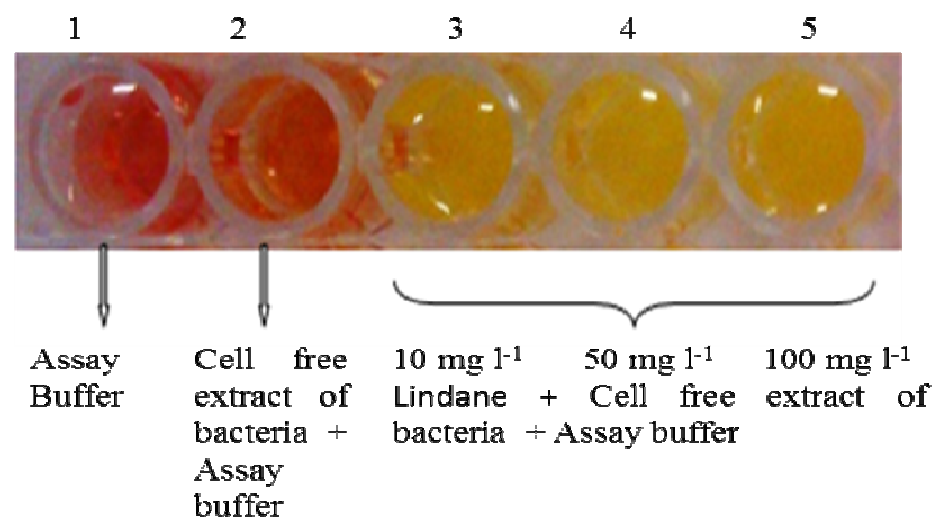

Fig. 3. Lindane dechlorination assay. Well A: assay buffer; B: assay buffer and cell free extract of Arthrobacter sp. T16; C, D, E: assay buffer, cell free extract of bacteria and substrate (lindane $10 \mathrm{mg} \mathrm{l}^{-1}, 50 \mathrm{mgl}^{-1}$ and $100 \mathrm{mg} \mathrm{l}^{-1}$ )

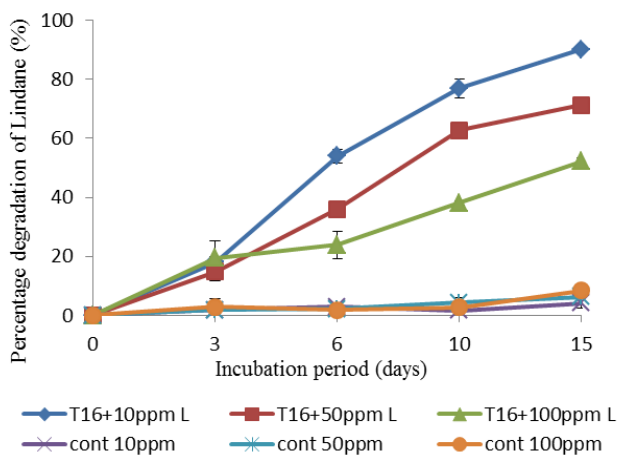

Fig. 4 Biodegradation of lindane at its different concentration (10 $\mathrm{mg} \mathrm{l}^{-1}, 50 \mathrm{mg} \mathrm{l}^{-1}$ and $100 \mathrm{mg} \mathrm{l}^{-1}$ ) by Arthrobacter sp. T16. Values are mean of three replicates. Error bars show \pm SE. Cont- control
Table 2. Average rate and kinetic parameters for lindane degradation by Arthrobacter sp. T16

\begin{tabular}{ccccc}
\hline $\begin{array}{c}\text { Lindane } \\
\begin{array}{c}\text { concentration } \\
\left(\mathrm{mg} \mathrm{l}^{-1}\right)\end{array}\end{array}$ & $\begin{array}{c}\text { Average rate of } \\
\text { degradation } \\
\left(\mathrm{mg} \mathrm{l}^{-1} \text { day }^{-1}\right)\end{array}$ & $\mathrm{K}\left(\mathrm{d}^{-1}\right)$ & $\mathrm{T}_{1 / 2}(\mathrm{~d})$ & $\mathrm{R}^{2}$ \\
\hline 10 & 0.60 & 0.156 & 4.44 & 0.975 \\
50 & 2.37 & 0.088 & 7.9 & 0.965 \\
100 & 3.48 & 0.052 & 13.3 & 0.985 \\
\hline
\end{tabular}


Table 3. Significant protein score, sequence coverage, matched protein and mass for unique protein bands of Arthrobacter sp. T16

\begin{tabular}{ccccc}
\hline & $\begin{array}{c}\text { Significant } \\
\text { protein score }\end{array}$ & $\begin{array}{c}\text { Sequence } \\
\text { coverage }\end{array}$ & Matched protein & Mass (kD) \\
\hline Band 1 & 283 & $38 \%$ & putative ABC transporter periplasmic amino acid-binding protein & 36.8 \\
Band 2 & 137 & $50 \%$ & elongation factor Tu & 43.0 \\
Band 3 & 57 & $8 \%$ & $\begin{array}{c}\text { trifunctional transcriptional regulator/proline } \\
\text { dehydrogenase/pyrroline-5-carboxylate dehydrogenase }\end{array}$ & 137.3 \\
\hline
\end{tabular}
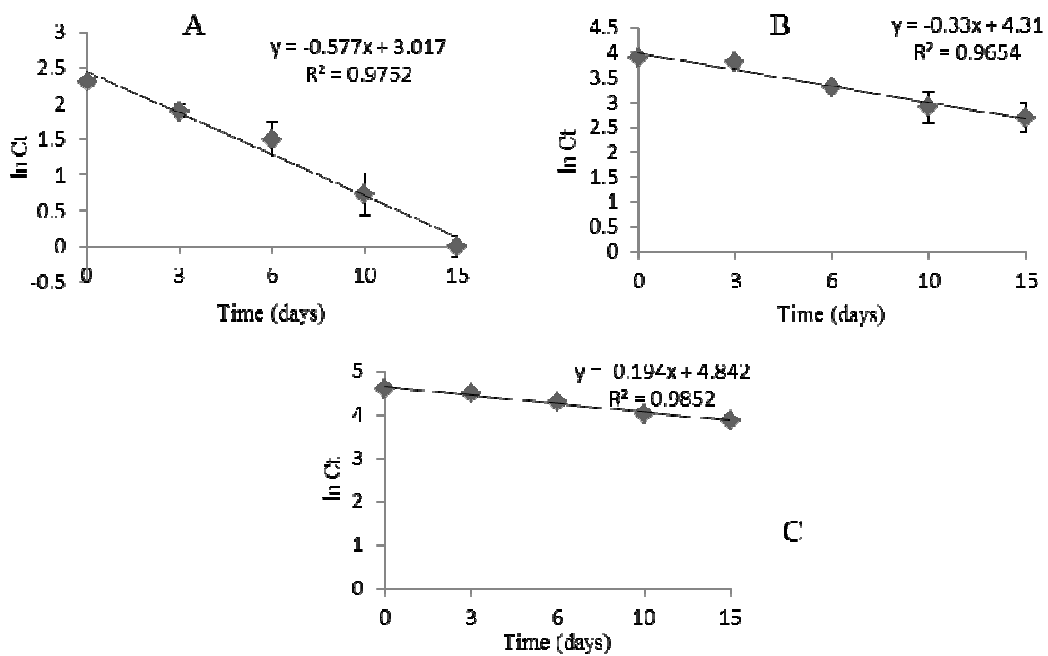

Fig. 5. Kinetic plot of first order reaction for lindane degradation by Arthrobacter sp. T16A-10 mg l-1 lindane; B-50 mg l-1 lindane; C-100 $\mathrm{mg} \mathrm{l}^{-1}$ lindane

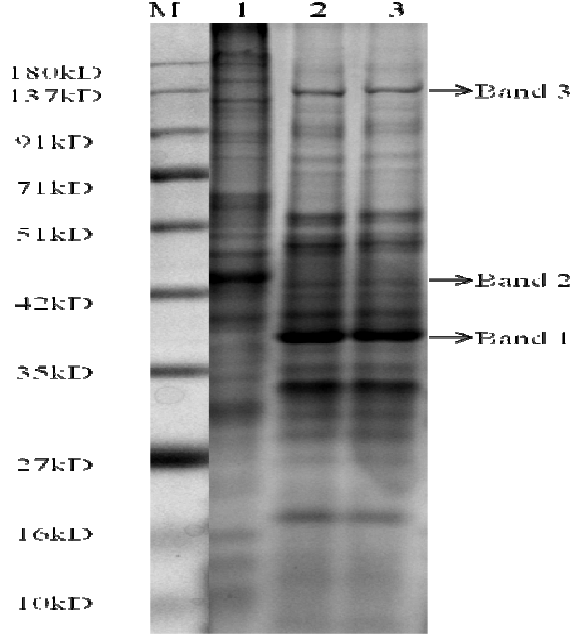

Fig. 6 SDS-PAGE gel presenting protein profile of Arthrobacter sp. T16. M: protein marker (10-180 kD). Lane 1: MSM with glucose, lane 2 and 3: MSM with lindane. Band 1,2,3 designate distinctive polypeptide bands in lane 2 and 3

Identification was done by digesting the proteins with trypsin and subjecting to MALDI-TOF and MS/MS analysis. Mass spectra of polypeptides revealed intense peaks which were subjected to Mascot Search against the NCBI database. Table 3 shows the matched protein for each corresponding protein band of Arthrobacter sp. T16 with significant protein score and sequence coverage. Polypeptide band 1 was identified as putative $A B C$ transporter periplasmic amino acid-binding protein. This protein is involved in transporter activity which allows the movement of macromolecules, ions and small molecules into or out of the cell. Gram negative bacteria have solute binding proteins dissolved in the periplasm and take part in transmembrane transport. For example, In Sphingomonas paucimobilis UT26, genes for ABC-transporter system are necessary for lindane utilization (Endo et al., 2007). As a result the extracellular solute-binding protein expressed in the presence of lindane could be involved in lindane transport inside the bacterial cell. Polypeptide band 2 was identified as elongation factor $\mathrm{Tu}$. Elongation factor $\mathrm{Tu}$ is one of the prokaryotic elongation factors. Elongation factors are component of the system that synthesizes new proteins by translation at the ribosome. Elongation factor Tu catalyzes the formation of acyl bond between incoming amino acid residue and peptide chain. Elongation factor-Tu may be concerned in protection from stress (Caldas et al., 1998) and in our study, this was expressed when bacterial cell was exposed to lindane stress. In Delftia acidovorans, the response to chlorophenoxy acid stress showed upregulation of one isoform of elongation factor-Tu (Benndorf et al., 2004). Elongation factor-Tu has been reported to be upregulated in Pseudomonas putida under toluene stress (Segura et al., 2005). Polypeptide band 3 was identified as trifunctional transcriptional regulator / proline 
dehydrogenase / pyrroline-5-carboxylate dehydrogenase. Proline is a proteinogenic secondary amino acid, which plays essential role in primary metabolism, osmotic adjustment, redox homeostasis, protection against stress and signaling in all organisms (Servet et al., 2012). Proline synthesis takes place from glutamate by delta-1-pyrroline-5carboxylate synthetase and delta-1-pyrroline-5-carboxylate reductase. Proline gets converted back to glutamate by proline dehydrogenase and delta-1-pyrroline-5-carboxylate dehydrogenase. In gram-negative bacteria, proline dehydrogenase and delta1-pyrroline-5-carboxylate dehydrogenase domains are fused together in single protein known as proline utilization (PutA) protein. In response to environmental stress proline accumulation occurs in bacteria (Liang et al., 2013). When Arthrobacter sp. T16 was exposed to lindane stress, this protein was expressed. Moreover, Perez-Arellano et al. (2010) observed that under stress conditions, some bacteria accumulate proline at a concentration well above which is needed. Therefore, catabolism of proline to glutamate occurs by proline dehydrogenase and delta-1-pyrroline-5-carboxylate dehydrogenase. In another study it has been observed that proline serves as nutrient for Bacillus subtilis. These cells seek proline through chemotaxis and then import it through the OpuE-related PutP transporter for catabolism to glutamate (Moses et al., 2012; Zaprasis et al., 2013).

Therefore, alteration in protein profile and configuration of new proteins might be serving bacteria to bear unfavorable stress environment. Our outcome tend to concur with studies of Rajendran et al. (2007) and Kumar et al. (2011) that have reported the production of new proteins under stress environment.

\section{Conclusions}

This study reveals the presence of lindane degrading bacteria in the roots of wetland plant Typha latifolia. To the best of our knowledge, there have been no reports on lindane degrading root epiphytic bacteria from Typha latifolia. This study specifies the potential of phytoremediation in controlling the environmental contamination problem with the help of contaminant degrading indigenous organisms present in the roots of plants.

\section{Acknowledgements}

This work was supported by Indian Council of Agricultural Research, New Delhi, India, as research project entitled "Bioremediation of contaminants in polluted sites: Use of weedy plants" NFBSFARA/ WQ3032/2013-14.

\section{References}

Abhilash PC, Srivastava S, Srivastava P, Singh B, Jafri A, Singh N (2011). Influence of rhizospheric microbial inoculation and tolerant plant species on the rhizoremediation of lindane.Environmental and Experimental Botany 74:127-130.

Alvarez A, Benimeli CS, Saez JM, Fuentes MS, Cuozzo SA, Polti MA,
Amoroso MJ (2012a). Bacterial bio-resources for remediation of hexachlorocyclohexane. International Journal of Molecular Sciences 13(11):15086-15106.

Alvarez A, Yañez ML, Benimeli CS, Amoroso MJ (2012b). Maize plants (Zea mays) root exudates enhance lindane removal by native Streptomyces strains. International Biodeterioration and Biodegradation 66(1):1418.

Benimeli CS, Castro G, Chaile A, Amoroso MJ (2007).Lindane uptake and degradation by aquatic Streptomycessp. strain M7.International Biodeterioration and Biodegradation 59(2):148-155.

Benimeli CS, Fuentes MS, Abate CM, Amoroso MJ (2008). Bioremediation of lindane-contaminated soil by Streptomyces sp. M7 and its effects on Zea mays growth. International Biodeterioration and Biodegradation 61(3):233-239.

BenndorfD, Davidson I, Babel W (2004). Regulation of catabolic enzymes during long-term exposure of Delftia acidovorans $\mathrm{MC1}$ to chlorophenoxy herbicides. Microbiology 150(4):1005-1014.

BöltnerD, Godoy P, Muñoz-Rojas J, DuqueE, Moreno-Morillas S, Sánchez L, Ramos JL (2008). Rhizoremediation of lindane by root-colonizing Sphingomonas. Microbial Biotechnology 1(1):87-93.

Caldas T, El Yaagoubi A, Richarme G (1998). Chaperone properties of bacterial elongation factor EF-Tu. Journal of Biological Chemistry 273(19):11478-11482.

Camacho-Pérez B, Ríos-Leal E, Rinderknecht-Seijas N, Poggi-Varaldo HM (2012). Enzymes involved in the biodegradation of hexachlorocyclohexane: a mini review. Journal of Environmental Management 95:S306-S318.

Cuozzo SA, Rollán GG, Abate CM, Amoroso MJ (2009). Specific dechlorinase activity in lindane degradation by Streptomyces sp. M7. WorldJournal of Microbiology \& Biotechnology 25(9):1539-1546.

Datta J, Maiti AK, Modak DP, Chakrabartty PK, Bhattacharyya P, Ray PK (2000). Metabolism of $\gamma$-hexachlorocyclohexane by Arthrobacter citreus strain BI-100: identification of metabolites. Journal of General and Applied Microbiology 46(2):59-67.

De Paolis MR, Lippi D, Guerriero E, Polcaro CM, Donati E (2013). Biodegradation of $\alpha$ - $\beta$-, and $\gamma$-hexachlorocyclohexane by Arthrobacter fuorescens and Arthrobacter giacomelloi. Applied Biochemistry and Biotechnology 170(3):514-24.

Draft Risk Management Evaluation for Lindane (2007). Persistent Organic Pollutants Review Committee (POPRC) Stockholm Convention on persistent organic pollutants. Retrieved 2018 May 21 from http://www.pops.int/documents/meetings/poprc/drprofile/drme/Dr aftRME_Lindane.pdf.

Egorova DO, Buzmakov SA, Nazarova EA, Andreev DN, Demakov VA, Plotnikova EG (2017). Bioremediation of hexachlorocyclohexanecontaminated soil by the new Rhodococcus uratislaviensis strain Ch628. Water Air Soil Pollution 228(5):183-199.

Endo R, Ohtsubo Y, Tsuda M, Nagata Y (2007). Identification and characterization of genes encoding a putative ABC-type transporter essential for utilization of $\gamma$-hexachlorocyclohexane in Sphingobium japonicum UT26.Journal of Bacteriology 189(10):3712-3720.

Fuentes MS, Benimeli CS, Cuozzo SA, Amoroso MJ (2010a). Isolation of pesticide-degrading actinomycetes from a contaminated site: bacterial 
566

growth, removal and dechlorination of organochlorine pesticides. International Biodeterioration and Biodegradation 64(6):434-441.

Fuentes MS, Benimeli CS, Cuozzo SA, Saez JM, Amoroso MJ (2010b). Microorganisms capable to degrade organochlorine pesticides. Current Research, Technology and Education Topics in Applied Microbiology and Microbial Biotechnology1255-1264.

Gerhardt KE, Huang XD, Glick BR, Greenberg BM (2009). Phytoremediation and rhizoremediation of organic soil contaminants: potential and challenges. Plant Science 176(1): 20-30.

Giri K, Rawat AP, Rawat M, Rai JPN (2014). Biodegradation of hexachlorocyclohexane by two species of bacillus isolated from contaminated soil. Chemistry andEcology 30(2):97-109.

Iwasaki I, Utsumi S, Ozawa T (1952). New colorimetric determination of chloride using mercuric thiocyanate and ferric ion. Bulletin of the Chemical Society ofJapan 25(3):226-226.

Jennings AA, LiZ (2014). Scope of the worldwide effort to regulate pesticide contamination in surface soils. Journal of Environmental Management 146:420-443.

Kaur J, Moskalikova H, Niharika N, Sedlackova M, Hampl A, Damborsky J, Prokop Z, Lal R (2013). Sphingobium baderi sp. nov, isolated from a hexachlorocyclohexane dump site. International Journal of Systematic andEvolutionary Microbiology 63(2):673-678.

Khan S, Afzal M, Iqbal S, Khan QM (2013). Plant-bacteria partnerships for the remediation of hydrocarbon contaminated soils. Chemosphere 90(4):1317-1332.

Kumar N, Kumar RN, Bora A, Amb MK (2011). An evaluation of pesticide stress induced proteins in three cyanobacterial species Anabaena fertilissima, Aulosira fertilissima and Westiellopsisprolifica using SDS-PAGE. World Academy of Science, Engineering and Technology 5(3):139-146.

Lal R, Pandey G, Sharma P, Kumari K, Malhotra S, et al., Oakeshott JG (2010). Biochemistry of microbial degradation of hexachlorocyclohexane and prospects for bioremediation. Microbiology and Molecular Biology Reviews 74(1):58-80.

Liang XW, Zhang L, Natarajan SK, Beckker DF (2013). Proline Mechanisms of stress survival. Antioxidants \& Redox Signaling 19(9):998-1011.

Miguel AS, Roy J, Gury J, Monier A, Coissac E, Ravanel P, Geremia RA, Raveton M (2014). Effects of organochlorines on microbial diversity and community structure in Phragmites australis rhizosphere. Applied Microbiology and Biotechnology 98(9):4257-66.

Moses S, Sinner T, Zaprasis A, Stöveken N, Hoffmann T, Belitsky BR, Sonenshein AL, BremerE (2012). Proline utilization by Bacillus subtilis: uptake and catabolism. Journal of Bacteriology 194(4):745-758.

Paul S, Paul B, Khan MA, Aggarwal C, Thakur JK, Rathi MS (2013). Effects of Lindane on Lindane-Degrading Azotobacter chroococcum; Evaluation of Toxicity of Possible Degradation Product(s) on Plant and Insect. Bulletin of Environmental Contamination and Toxicology 90(3):351-356.

Pérez DJ, Menone ML, Camadro EL, Moreno VJ (2008). Genotoxicity evaluation of insecticide endosulfan in the wetland macrophyte Bidens laevis L. Environmental Pollution 153(3):695-698.

Perez-Arellano I, Carmona-Alvarez F, Martinez AI, Rodriguez-Diaz J, Cervera J (2010). Pyrroline-5-carboxylate synthase and proline biosynthesis: from osmotolerance to rare metabolic disease. Protein Science 19(3):372-382.
Pesce SF, Wunderlin DA (2004). Degradation of Lindane by a native bacteria consortium isolated from contaminated river sediment. International Biodeterioration and Biodegradation 54(4):255-260.

Philip C, Shrivastava AK, Shrivastava R (2014). Effect of organochlorine pesticide on growth of Actinomycetes. Indian Journal of Scientific Research 4(1):191-195.

Phillips TM, Seech AG, Lee H, Trevors JT (2001). Colorimetric assay for Lindane dechlorination by bacteria. Journal of Microbiological Methods 47(2):181-8.

Polti MA, Aparicio JD, Benimeli CS, Amoroso MJ (2014). Simultaneous bioremediation of $\mathrm{Cr}$ (VI) and lindane in soil by Actinobacteria. International Biodeterioration and Biodegradation 88:48-55.

Rajendran UM, Elango K, Anand N (2007). Effects of a Fungicide, an Insecticide and a Biopesticide on Tolypothrix scytonemoides. Pesticide Biochemistryand Physiology 87(2):164171.

Saez JM, Aparicio JD, Amoroso MJ, Benimeli CS (2015). Effect of the acclimation of a Streptomyces consortium on lindane biodegradation by free and immobilized cells. Process Biochemistry 50(11):1923-1933.

Sagar V,Singh DP (2011). Biodegradation of lindane pesticide by non whiterots soil fungus Fusarium sp. World Journal of Microbiology \& Biotechnology 27(8):1747-1754.

Salam JA, Lakshmi V, Das D, Das N (2013). Biodegradation of lindane using a novel yeast strain, Rhodotorula sp. VITJzN03 isolated from agricultural soil. World Journal of Microbiology \& Biotechnology 29(3):475-487.

Segura A, Godoy P, van Dillewijn P, Hurtado A, Arroyo N, Santacruz S, Ramos JL (2005). Proteomic analysis reveals the participation of energyand stress-related proteins in the response of Pseudomonas putida DOTT1E to toluene. Journal of Bacteriology 187(17):5937-5945.

Servet C, Ghelis T, Richard L, Zilberstein A, Savoure A (2012). Proline dehydrogenase: a key enzyme in controlling cellular homeostasis. Frontiers in Bioscience 17(1):607-620.

Singh M, Singh DK (2014). Endosulfan induced alteration in bacterial protein profile and RNA yield of Klebsiella sp. M3, Achromobacter sp. M6, and Rhodococcus sp. M2. Journal of Hazardous Materials 265:233241.

Singh T, Singh DK (2017). Phytoremediation of organochlorine pesticides: Concept, method, and recent developments. International Journal of Phytoremediation 19(9):834843.

Strungaru SA, Nicoara M, Jitar O, Plavan G (2015). Influence of urban activity in modifying water parameters, concentration and uptake of heavy metals in Typha latifolia L. into a river that crosses an industrial city. Journal of Environmental Health Science \& Engineering 13(1):5.

Sukumaran D (2013). Phytoremediation of heavy metals from industrial effluent using constructed wetland technology. Applied Ecology and Environmental Sciences 1(5):92-97.

Vijgen J, Abhilash PC, Li YF, Lal R, Forter M, Torres J, Singh N, Yunus M, Tian C, Schäffer A, Weber R (2011). Hexachlorocyclohexane (HCH) as new Stockholm convention POPs-a global perspective on the management of Lindane and its waste isomers. Environmental Science and Pollution Research 18(2):152-162.

Zaprasis A, Brill J, Thüring M, Wünsche G, Heun M, et al., Bremer E (2013). Osmoprotection of Bacillus subtilis through import and proteolysis of proline-containing peptides. Applied and Environmental Microbiology 79(2):576-587 